\title{
AFLP Molecular Identification and Genetic Relationship of Chinese and Japanese Pear Cultivars Grown in Middle European Conditions
}

\author{
Jan WOLF $^{1 *}$, Kateřina BARÁNKOVÁ², Tomáš NEČAS ${ }^{1}$ \\ ${ }^{1}$ Mendel University in Brno, Faculty of Horticulture in Lednice, Department of Fruit Growing, Valtická 337, Lednice, 69144, \\ Czech Republic; xwolf1@node.mendelu.cz(*correspondingauthor); tomas.necas@mendelu.cz \\ ${ }^{2}$ Mendel University in Brno, Faculty of Horticulture in Lednice, Mendeleum - Department of Genetics, Valtická 337, Lednice, 69144, \\ CzechRepublic;xmoravc2@node.mendelu.cz
}

\begin{abstract}
In this study, 30 genotypes of genus Pyrus (five European cultivars, 16 Asian cultivars, three rootstocks, four interspecific hybrids, one landrace cultivar from Czech Republic ('Krvavka'), Pyrus betulaefolia Bunge. and one intergeneric hybrid (Cydomalus)) were tested using AFLP markers. Twelve primer combinations generated a number of 1251 fragments of which 1064 were polymorphic with an average polymorphism of $85.3 \%$. The dendrogram, created by using the UPGMA method, revealed a distinct genetic relationship between European and Asian pear groups. The intergeneric hybrid Cydomalus was separated in the cluster tree from both groups. The level of similarity coefficient between European and Asian pears was 0.75 . Despite the fact that Pyrus betulaefolia Bunge was clustered in the European pear group, the average similarity coefficient between the European pear group and Pyrus betulaefolia Bunge (0.7704) was comparable to the similarity coefficient between the Asian pear group and Pyrus betulaefolia Bunge (0.768). Thus, the botanic species Pyrus betulaefolia Bunge can likely be considered as an intermediate genotype between European and Asian pears. The cultivar 'Talgarskaja Krasavica' (chance seedling of 'Forest Beauty'), which pomologically belongs to the European pear group was clustered together with the interspecific hybrid 'Wu Jiu Xinag' ('Ya Li' $\times$ 'Bartlett') which on the other hand belongs to the Asian pear group. Thus, due to its position in the dendrogram the cultivar 'Talgarskaja Krasavica' could be considered as an interspecific hybrid.
\end{abstract}

Keywords: AFLP, Asian pear, European pear, genetic relationship, Pyrus

\section{Introduction}

Pears are the third most important temperate fruit species after apples and grapes (Wu et al., 2013). They belong to the family Rosaceae, subfamily Pomoideae, genus Pyrus ( $2 n=34$ chromosomes) (Jackson, 2003). Pyrus is a polymorphous genus from the northern hemisphere (Bailey, 1917) which includes 22 primary species, at least six naturally interspecific hybrids, and at least three artificial hybrids (Bell et al., 1996). The genus Pyrus originates in Tertiary period (65-55 million years ago) in the foothills of the Tian Shan mountain massif in province Xinjang in western China. Progenitor pear genotypes can be found in the Chinese gene center, the central Asiatic gene center and the Near Eastern gene center (Vavilov, 1951).

Due to geographic and climatic factors, two groups were created: the Oriental (Asian) pear group and the Occidental (European) pear group (Bailey, 1917). The Oriental pear group is divided into five subgroups: Ussurian pears,
Chinese white pears, Xinjiang pears, Chinese sand pears and Japanese pears. Cultivars of Ussurian pears undoubtedly originated from Pyrus ussuriensis Max, which naturally grows in northeastern China and the northern part of Heibei and Shanxi provinces (Shen, 1980). The group of Chinese white pears arose from Pyrus $\mathrm{x}$ bretschneideri Rehd. (P. ussurinesis $\times P$. betulifolia). Japanese pears derived from wild Pyrus pyrifolia (Burm.) Nak., which originates in Middle and Southern Japan (Teng, 2004). Like Japanese pears, Chinese sand pears also arose from Pyrus pyrifolia (Burm.) Nak. (Shen, 1980). Japanese pears arose from progenitor genotypes which were introduced from ancient China via sea trade connecting Kochi Prefecture of Japan and Zhejing Province of China (Teng et al., 2001, 2002; Shen et al., 2006; Bao et al., 2007, 2008). Xinjiang pears grown in Xinjiang Uygur Autonomous Region originate from Pyrus $\mathrm{x}$ sinkiangensis $(P$. communis $\mathrm{L} . \times P . \mathrm{x}$ bretschneideri Rehd.) (Teng et al., 2001). 
370

The origins of pear growing in the Czech Republic have not been conclusively substantiated yet. One theory states that our ancestors gained knowledge of pear cultivation from neighboring Germanic countries or that they had direct contact with the Romans (Koch, 1967). The second theory says that pear trees were brought to our territory by Slavs during migrations between the $4^{\text {th }}$ to $7^{\text {th }}$ centuries. In the second half of the $19^{\text {th }}$ century the most significant pear orchards were established in the Lower Elbe region. These orchards became the production and export centers for the Czech Republic and the famous Czech pears were crossing borders (Koch, 1967). In 1955 the annual harvest was 35,582 tons of pears (Koch, 1967); in 2010 the annual harvest of pears was only 16,157 tons, however in 2012 new orchards of total area of 326 ha were established in the Czech Republic (FAO, 2016).

In the last century numerous methods have been used for distinguishing the relatedness and origins of pear cultivars. Kikuchi (1946) and Yu (1979) described the taxonomy of Chinese and Japanese pears using morphological and pomological characters. Lin and Shen (1983) divided pear cultivars using peroxidase isozymic pattern and Zou et al. (1986) divided pear cultivars based on pollen ultrastructure. After the development of the PCR method a lot of molecular methods were developed, which are used to determine the genetic diversity, e.g. RAPD (Williams et al., 1990; Welsh and McClelland M, 1990), SSR (Tautz et al., 1986; Powell et al., 1996) and AFLP (Vos et al., 1995). For example, 20 RAPD markers were used for division of 72 Asian and European pears into 5 genetic groups (Teng et al., 2001), while by use of 6 SSR markers another set of 98 Pyrus genotypes were divided into 10 groups (Bao et al., 2007) and finally 6 AFLP markers used for division of 100 Pyrus genotypes created 15 groups (Bao et al., 2008). Based on these methods, new relationships between cultivars and wild species were discovered. In spite of these advancements and findings, the taxonomy of genus Pyrus is still unstable (BAO et al., 2008).

Amplified Fragment Length Polymorphism (AFLP) is a suitable method for molecular identification in many studies concerning plants, animals, fungi, bacteria, and many other subjects in genetics, ecology, and evolution and was introduced in 1995 (Vos et al., 1995). AFLP technology is a powerful DNA fingerprinting technique, which combines DNA restriction and PCR amplification (Cervera et al., 1996). The main benefit of this method is its high polymorphism in plastid DNA unlike the SSR (Simple Sequence Repeats) method, which has really low polymorphism in the plastid DNA region (Bensch and Akesson, 2005).

The aim of this study was to assess the genetic relationship between cultivars of European pear and Asian pear groups grown in the Czech Republic. Several of the Asian pear group cultivars have had their names modified to Czech language in the past, consequently the original names are unknown along with their family genealogy. Determination of taxonomic relationships between pear cultivars, particularly Asian pear group cultivars grown in Czech Republic, can be useful to deduce their likely origin and to help in selection of progenitors for breeding programs.

\section{Materials and Methods}

\section{Plantmaterial}

In the current study, 30 pear genotypes were evaluated including five European pear group cultivars, one landrace 'Krvavka' (from White Carpathians), 16 Asian pear group cultivars, three rootstocks, four interspecific hybrids, Pyrus betulaefolia Bunge, and the intergeneric hybrid Cydomalus (Table 1).

\section{DNAisolation}

Genomic DNA was isolated from young leaves. The DNA was isolated from $100 \mathrm{mg}$ of crushed leaves using DNeasy Plant Mini Kit by Qiagen. The quality of isolated DNA was assessed by electrophoresis in $1 \%$ agarose gel and the concentration was measured by Modulus ${ }^{\mathrm{TM}}$ Single Tube Fluorometer 9200 - 000 (TURNER BIOSYSTEMS, USA).

\section{AFLP analysis}

For the restriction phase, $200 \mathrm{ng}$ of genomic DNA was used. DNA was digested at $37^{\circ} \mathrm{C}$ for 12 hours by a mixture of the restriction enzyme EcoRI (10 U) and MseI (2 U). After the restriction phase, DNA fragments were ligated to the EcoRI adaptor $(5 \mathrm{pM})$ and the MseI adaptor $(50 \mathrm{pM})$ in a mixture with $1 \times$ NEB buffer 2 , ATP $(100 \mathrm{mM})$ and T4 DNA ligase $(100 \mathrm{U})$ at $16^{\circ} \mathrm{C}$ for 12 hours. Digest-ligated DNA fragments (primary templates) were diluted $10 x$ from which $10 \mu$ of was used in the pre-amplification phase. Total volume of PCR reaction was $50 \mu$ l containing: $1 \times$ PCR buffer, dNTPs $(25$ $\mathrm{mM})$, primer EcoRI - preamp (100 ng), primer MseI preamp (100 ng), Taq polymerase (1.25 U) and HPLC water. The program consisted of 20 cycles at $94^{\circ} \mathrm{C}$ for 45 seconds followed by $52^{\circ} \mathrm{C}$ for 45 seconds and $72^{\circ} \mathrm{C}$ for 60 seconds. The product of pre-amplification phase, the secondary template, was diluted $10 \times$. For the last, selective amplification phase, twelve primer combinations were used (Table 2). Primer combinations consisted of four Mse I primers and three Eco RI primers which were labelled by fluorescent NED, FAM, and JOE dyes. Four sets of three variants were formed using one Mse I primer and three Eco RI primers.

The total volume of the selective amplification reaction was $15 \mu \mathrm{l}$ consisting of $5 \mu \mathrm{l}$ of secondary template, $1 \times$ PCR buffer, dNTPs $(25 \mathrm{mM})$, primers Eco RI (5 pmol) and Mse I (15 pmol), Taq polymerase (2 U), and HPLC water. A touchdown PCR program was used consisting of 10 cycles at $94^{\circ} \mathrm{C}$ for 30 seconds followed by $65^{\circ} \mathrm{C}$ to $56^{\circ} \mathrm{C}$ (decreasing by $0.7^{\circ} \mathrm{C}$ in each consecutive cycle) for 30 seconds and $72^{\circ} \mathrm{C}$ for 60 seconds, and then 24 cycles at $94^{\circ} \mathrm{C}$ for 30 seconds followed by $56^{\circ} \mathrm{C}$ for 30 seconds and $72^{\circ} \mathrm{C}$ for 60 seconds.

PCR products from each set were mixed $(6 \mu \mathrm{lNED}+4 \mu \mathrm{l}$ FAM $+4 \mu \mathrm{lJOE}$ ). Two microliters of the sample mixture were mixed with $12 \mu \mathrm{l}$ formamide and $0.5 \mu \mathrm{l}$ GS ROX 500 size standard and were heat-denatured at $95^{\circ} \mathrm{C}$ for five minutes and cooled down using ice. Samples were afterwards measured by genetic analyser ABI PRISM $310^{\circ}$ (Applied Biosystems).

\section{Data analysis}

Data were analysed using the GeneScan Analysis (Applied Biosystems) program. Samples were analysed for presence and absence of fragments. The results were written in a table as follows: $1=$ presence of a fragment, $0=$ absence of a fragment. 
Table 1. Pyrus species included in the current study

\begin{tabular}{|c|c|c|c|}
\hline Name & Species & Lineage & Origin \\
\hline Cydomalus & Intergeneric hybrid & Malus domestica $\times$ Cydonia oblonga & Rusia \\
\hline 'Hosui' & P. pyrifolia & Ri - 14 ('Kikusui' × 'Yakumo') × 'Yakumo' & Japan 1954 \\
\hline ‘Chojuro' & P.pyrifolia & Chance seedling & Japan 1889 \\
\hline 'Jinhua' & P. $\times$ bretschneideri & Unknown & Unknown \\
\hline 'Ju Li' & Unknown & Unknown & Unknown \\
\hline 'Kirgizkaja Zimnaja' & Unknown & Unknown & Unknown \\
\hline 'Kumt Ghant Chu' & Unknown & Unknown & Unknown \\
\hline 'Nijisseiki' & P.pyrifolia & Chance seedling & Japan 1898 \\
\hline 'Ping Guo Li' & P. ussuriensis & Old selection from Beijing Municipality & China \\
\hline 'Pung Su' & Unknown & Unknown & Unknown \\
\hline 'Shin Li' & P. pyrifolia & 'Kikusui' × ‘Tsu Li' & California 1988 \\
\hline ‘Shinko’ & P. pyrifolia & Chance seedling 'Nijisseiki' & Japan 1941 \\
\hline 'Kumoi' & P. pyrifolia & 'Ishii Wase' × 'Yakumo' & Japan 1955 \\
\hline 'Shinseiki' & P.pyrifolia & 'Nijisseiki' × 'Chojuro' & Japan 1945 \\
\hline 'Shon Shu' & P.xbretschneideri & Unknown & China \\
\hline 'Talgarskaja Krasavica’ & Unknown & Chance seedling Forest Beauty & Kazakhstan \\
\hline 'Wu Jiu Xiang' & Interspecific hybrid & 'Ya Li' × ‘Bartlett' & Unknown \\
\hline 'Xue Hua Li' & P. x bretschneideri & Unknown & Unknown \\
\hline 'Ya Li' & P. $x$ bretschneideri & Old special, unknown & China \\
\hline 'Zao Su Li' & P. $x$ bretschneideri & 'Ping Guo Li' × 'Shenbuzhi' & China 1977 \\
\hline 'Hood' & Interspecific hybrid & Oriental $\times$ Occidental hybrid & Florida \\
\hline 'Kieffer' & Interspecific hybrid & $P$. pyrifolia $\times$ 'Bartlett' & Philadelphia 1863 \\
\hline 'Rafzas' syn. 'Benita' & Interspecific hybrid & P. pyrifolia $\times$ 'General Leclerc' & Switzerland \\
\hline 'Krvavka' & P. communis & Landrace special & White Carpathians \\
\hline 'Fox 11' & P. communis (rootstock) & Chance seedling from 'Volpina' & Italy \\
\hline 'Clapp's favourite' & P. communis & 'Flemish Beauty' × 'Bartlett' & Massachusetts 1860 (USA) \\
\hline 'Conference' & P. communis & Seedling of 'Leon Leclerc de Laval' & England 1885 \\
\hline 'Bartlett' & P. communis & Chance seedling & England 1770 \\
\hline 'Pear seeding' & P. communis (rootstock) & Selection from old cultivars of pears & Czech Republic \\
\hline 'Pyrodwarf & P. communis (rootstock) & 'Old Home' × 'Bonne Luise d' Avraches' & Germany 1980 \\
\hline Pyrus betulaefolia & P. betulifolia (rootstock) & Botanical species & China \\
\hline
\end{tabular}

Table 2. The polymorphic characterization of AFLP primers in Pyrus

\begin{tabular}{cccc}
\hline Primer combination Eco/Mse & Number of evaluated fragments & Polymorphic fragments & Percentage of polymorphic fragments $(\%)$ \\
\hline E-ACT/M-TCGC & 101 & 92 & 91.1 \\
E-AGG/M-TCGC & 108 & 99 & 91.7 \\
E-AGC/M-TCGC & 103 & 98 & 95.1 \\
E-ACT/M-TCAA & 110 & 99 & 90.0 \\
E-AGG/M-TCAA & 99 & 88 & 88.9 \\
E-AGC/M-TCAA & 111 & 99 & 99.2 \\
E-ACT/M-GCAT & 105 & 95 & 88.5 \\
E-AGG/M-GCAT & 95 & 84 & 83.5 \\
E-AGC/M-GCAT & 115 & 96 & 85.3 \\
E-ACT/M-TACC & 95 & 81 & 85.0 \\
\hline E-AGG/M-TACC & 100 & 85 & 95.4 \\
\hline E-AGC/M-TACC & 109 & 104 & 89.5 \\
\hline Total & 1251 & 93.3 & \\
\hline Average & 104.3 & & \\
\hline
\end{tabular}

Results had a form of a binary matrix. Similarities of obtained spectra between any two variants were evaluated by the Nei and Li/Dice similarity index method by FreeTree program (Hampl et al., 2001). Using the cluster analysis method UPGMA (Bootstrap value 100) a dendrogram was constructed, which displays the degree of genetic similarity. Program TreeView $\mathrm{X}$ was used to achieve a better graphic representation.

\section{Results}

\section{AFLPpolymorphism}

Regarding the AFLP polymorphism, from a total of 1251 fragments (ranging from 90 to $500 \mathrm{bp}$ ) amplified with twelve primer combinations, a large amount of 1120 (89.5\%) fragments were polymorphic. The ability of individual primer pair to detect polymorphisms in the analysed genotypes is shown in Table 2. The highest polymorphism was found in primer combinations E-AGC/M-TCGC (98 polymorphic fragments, 95.1\%) and E-AGC/M-TACC (104 polymorphic fragments, $95.4 \%$ respectively). In contrast, primer combinations E-AGC/M-GCAT had the lowest polymorphism ( 96 polymorphic fragments, $83.5 \%$ ). 


\section{The cluster analysis}

The genetic distance dendrogram separated European pears and Asian pears, showing 0.75 similarity index between these two groups. The dendrogram was divided into three main clusters. The first cluster split into three groups: groups I. and II. - Asian pears and group III. - interspecific hybrids. The second cluster was split into four groups: group IV. - Pyrus betulaefolia Bunge, group V. - interspecific hybrids, groups VI. and VII. - European pears. The level of similarity coefficient between Asian pears was 0.81 and 0.79 between European pears. The third, distinctly separated cluster was comprised of Cydomalus, an intergeneric hybrid (Fig. 1).

Group I. consisted of Japanese pears. Group II. consisted of two Japanese pears 'Kumoi' and 'Hosui', five Chinese white pears 'Xue Hua Li', 'Jinhua', 'Shon Shu', 'Ya Li', 'Zao Su Li', one Ussurien pear 'Ping gou Li', one Chinese sand pear 'Shin $\mathrm{Li}$ ', and three pears with unknown origin 'Ju Li', 'Kumt Ghant Chu', and 'Pung Su'. The III. group consisted of 'Talgarskaja Krasavica' and 'Wu Jiu Xiang. Pyrus betulaefolia Bunge was clustered in group IV. Three interspecific hybrids 'Hood', 'Kieffer' and 'Rafzas' created group V. Occidental pears clustered in Groups VI. and VII.

The highest similarity coefficient (0.8998) was recorded between Japanese pears 'Nijissejki' and 'Shinko'. The second highest similarity coefficient $(0.89571)$ was found between Japanese pears 'Nijissejki' and 'Shinseiki'. The lowest similarity coefficients (0.62233 and 0.62763) were found between Cydomalus/'Talgarskaja Krasavica' and Cydomalus/'Wu Jiu Xiang', respectively.

\section{Discussion}

AFLP is considered to be the most effective method in examining genotyping of Pyrus communis L. and its cultivars (Monte-Corvo et al., 2002). The present results showed high polymorphism and demonstrate the suitability of AFLP method for genotyping. In this study the average percentage of polymorphic fragments was $89.5 \%$, which is higher by $2.5 \%$ than what was indicated by Monte-Corvo et al. (2000), which reported that the percentage of polymorphic groups within pear cultivars was $87 \%$. This difference is probably due to the fact that the presented research included an interspecific hybrid, botanical species, rootstocks, and intergeneric hybrid Cydomalus.

The similarity coefficients of investigated samples ranged from 0.8998 to 0.62233 . Based on these values it can be stated that the analysed genotypes can be considered as different cultivars. Cervera et al. (1998) stated that if the similarity coefficient between two samples is equal or higher than 0.9 , one of the samples might be considered a clone of the same cultivar.

Intergeneric hybrid Cydomalus, which derives from Malus domestica Borkh and Cydonia oblonga Mill crossing (De Paoli, 2002) was located in a separate cluster in dendrogram and its similarity coefficient with the other tested cultivars ranged from 0.622 to a relatively high value of 0.713 .

Shengua et al. (2002) stated that the similarity coefficient between Pyrus communis L. and Pyrus betulaefolia Bunge was measured to be 0.528 , however in this study, their similarity coefficient was measured to be 0.631 . This deviation is caused by the fact that the pear seedling (Pyrus communis L.) from this research was not a pure botanical species but a selected rootstock type pear seedling.

Challice and Westwood (1973) presented a closer relationship between Pyrus betulaefolia Bunge and European pear species concluding that Pyrus betulaefolia Bunge could be an intermediate type between European and Asian pears. Bao et al. $(2007,2008)$ found similar results using SSR and AFLP methods. In this work, the average similarity coefficient between European cultivars and Pyrus betulaefolia Bunge was 0.7704 and the average similarity coefficient between Asian cultivars and Pyrus betulaefolia Bunge was 0.768. Since this value is higher than the average similarity coefficients between European and Asian cultivars, it can be concluded that Pyrus betulaefolia Bunge is an intermediate type between European and Asian pears.

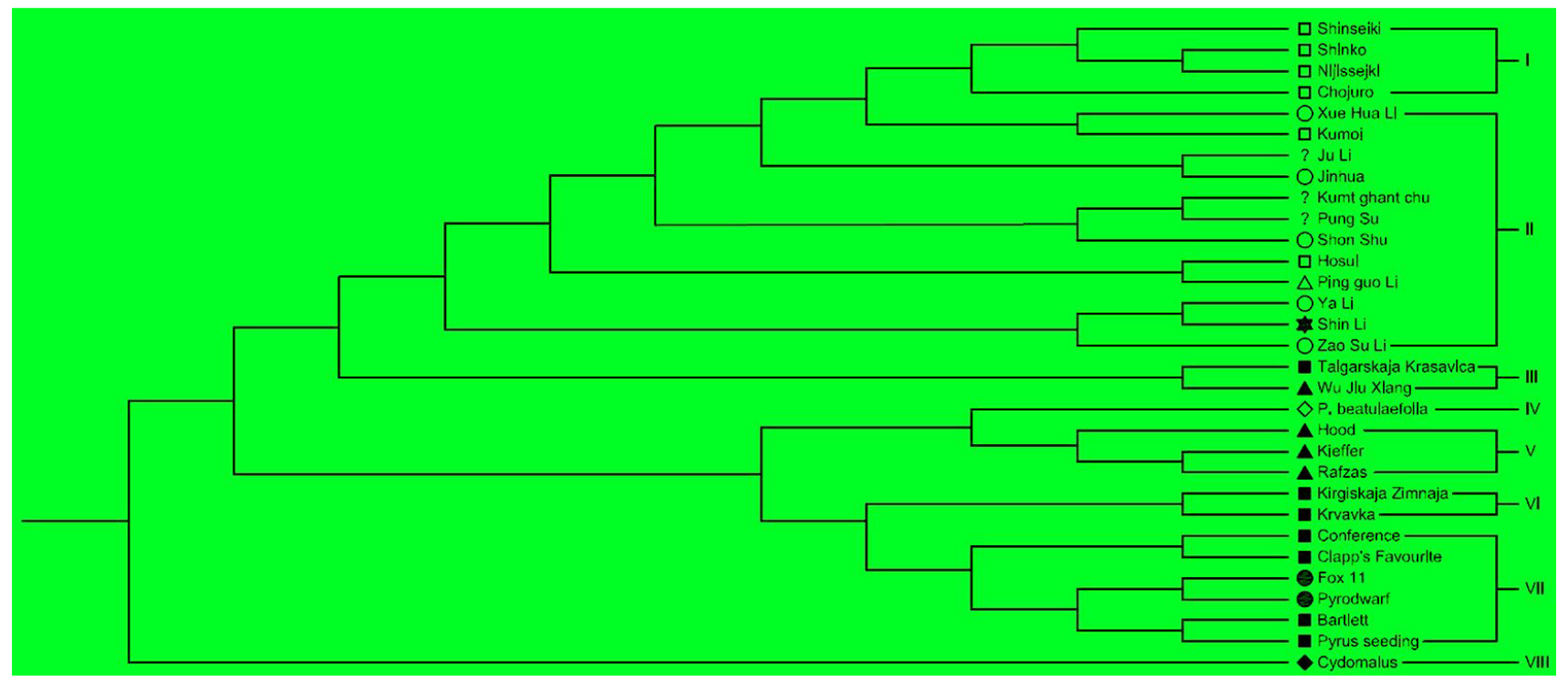

Fig. 1. Nei's genetic distance dendrogram of 31 interspecific hybrids and cultivars of pears was constructed using the UPGMA

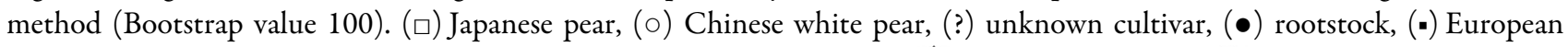
pear, $(\diamond)$ botanic species, $(\boldsymbol{\Delta})$ interspecific hybrid, $(\bullet)$ intergenetic hybrid, $(\boldsymbol{\nabla})$ Chinese sand pear, $(\triangle)$ Ussuriensis pear 
Chinese sand pears and Chinese white pears did not cluster in the dendrogram into separate groups and not even into subgroups, but they are mixed together. This aspect is also described in many other studies (Teng et al., 2002; Bao et al., 2007; Bao et al., 2008). Both pear types have similar pear peroxidase isozymic formula (Lin and Shen, 1983) and similar ultrastructure of pollen (Zou et al., 1986). Chinese white and Chinese sand pears are very similar in morphological and pomological characters as well, which suggests a very close genetic relationship between these two types. Bao et al. (2008) described a close genetic relationship of Chinese sand pear cultivars with certain Chinese white pear cultivars coming from Anhui Province, which is located in the northern border of the area from where the Chinese sandy cultivars started to spread. The results from evaluation of pomological characteristics show a relatively high degree of similarity in both types of pear cultivars but there are also significant cultivar differences (Nečas et al., 2016). Some differences between cultivars may occur due to different development and due to local geographic and climatic factors in isolated regions.

The origin of Japanese pear cultivars was considered to be the same as of Chinese sand pear cultivars, which derived from Pyrus pyrifolia (Burm.) Nak. Morphological and pomological characteristics of Japanese cultivars are very similar to Chinese sand cultivars (Teng et al., 2002). Bao et al. (2008) disclosed that Japanese pear cultivars are in the same cluster with some Chinese sand pears and Chinese white pears, especially those that come from Chinese Zhejiang province and provinces adjacent to it. Particularly some Japanese cultivars coming from Kochi Prefecture are very similar with certain Chinese sand pear cultivars of Zhejiang Province and Fujian. Probably the most likely theory is that ancient Chinese cultivars were brought to Japan through maritime trade route that once connected the Japanese prefecture of Kochi and the Chinese province of Zhejiang (Bao et al., 2007). Recent studies based on analyses of different DNA markers (Teng et al., 2001, 2002; Shen et al., 2006; Bao et al., 2007, 2008) concluded that Japanese pear cultivars could have developed from progenitor genotypes originating in ancient China. The same results were obtained in this work, as all the Japanese cultivars clustered in the same group as the Chinese sand pears.

In group I. all Japanese pears had high similarity indexes: 'Chojuro' (chance seedling from Japan), 'Shinko' (chance seedling from open pollinated variety 'Nijisseiki'), 'Shinseiki' (crossing varieties 'Nijisseiki' $\times$ 'Chojuro'), and 'Nijisseiki' (chance seedling from Japan). These cultivars have very similar pomological characters (Nečas et al., 2016) and their close relationships were confirmed in this study as well.

Group III., which is part of the third cluster of Oriental pears, consisted of interspecific hybrid 'Wu Jiu Xinag' ('Ya Li' $x$ 'Bartlett') (Gao, 2015) and 'Talgarskaja Krasavica' (chance seedling of 'Forest Beauty'). Group V. which is part of the second cluster of European pears, consisted of 'Hood' (Asian $\times$ European pear), 'Rafzas' (P. pyrifolia $\times$ 'General Leclerc'), and 'Kieffer' (P. pyrifolia $\times$ 'Bartlett'). Breeding studies with other genera showed that from the molecular point of view, interspecific hybrids are usually located somewhere between the parental species, but after several generations of segregation they usually drift closer to one of them (Simonovik et al., 2007). In the case of interspecific pears, during an interspecific recombination between cultivated and wild genotypes, the progeny probably drifted closer to the wild type, as wild cultivars have usually better chance of surviving (Sisko, 2009). The results of this study are in agreement with this knowledge and it can be assumed that cultivars 'Wu Jiu Xinag' and 'Talgarskaja Krasavica' belong to Asian pears and cultivars 'Hood', 'Rafzas', and 'Kieffer' belong to European pears.

European pear cultivars clustered in one group. The origin of all of these pears is Pyrus communis L. Pyrodwarf rootstock was bred from 'Old Home' and 'Bonne Louise d' Avranches' cultivar (Jacob, 1998) and Fox 11 rootstock is a progeny of an open pollinated 'Volpina' cultivar (Elkins et al., 2012). Cultivar 'Krvavka' is a landrace from White Carpathians (Czech Republic). 'Kirgizkaja Zimnaja' is a cultivar with unknown origin. Its morphological and pomological characters belong to European pears, but its fruit shape is similar to Chinese white pears (Nečas et al., 2016).

Tested cultivars of unknown origin were classified based on their similarity coefficient as follows: 'Ju Li' clustered in the same cluster as 'Jinhua' (0,842). 'Jinhua' and 'Ju Li' have similar morphological and pomological characters (Nečas et al., 2016). According to these results 'Ju Li' is probably a Chinese white pear. Varieties 'Kumt Ghant Chu' and 'Pung Su' have the highest similarity coefficient with 'Nijisseiki' $(0.85833$ and 0.8827 , respectively). Their morphological and pomological characters are very similar to 'Nijisseiki' (Nečas et al., 2016) and represent probably Japanese pear cultivars.

\section{Conclusions}

The molecular analyses used in this study enabled the placement of some unidentified genotypes into known cultivar groups. Molecular analyses also confirmed close relationship between Chinese white, Chinese sand and Japanese pear cultivars. Interesting results were found in clustering of interspecific hybrids and Pyrus betulaefolia Bunge.

\section{Acknowledgements}

This research was funded by project NAZV/KUS no. QJ1210036 by Ministry of agriculture of the Czech Republic.

\section{References}

Bailey LH (1917). Standard Cyclopedia of Horticulture Pymus, Vol 5. Macmillan, New York pp 2865-2878.

Bao L, Chen K, Zhang D, Cao Y, Yamamoto T, Teng Y (2007). Genetic diversity and similarity of pear (Pymus L) cultivars native to East Asia revealed by SSR (Simple Sequence Repeat) markers. Genetic Resources and Crop Evolution 54(5):959-971.

Bao L, Chen K, Zhang D, Li X, Teng Y (2008). An assessment of genetic variability and relationships within Asian pears based on AFLP (amplified fragment length polymorphism) markers. Scientia Horticulturae 116(4):374380.

Bell RL, Quamme HA, Layne REC, Skivin RM (1996). Pears. In: Janick J, Moore JN (Eds). Fruit breeding, tree and tropical fruits, Vol 1. John Wiley \& Sons, London pp 441-514.

Bensch S, Akesson M (2005). Ten years of AFLP in ecology and evolution: whyso few animals? Molecular Ecology 14(10):2899-2914. 
374

Cervera MT, Cabezas JA, Sancha JC, Martínez de Toda F, MartínezZApater JM (1998). Application of AFLPs to the characterization of grapevine Vitis vinifera L. genetic resources. A case study with accessions from Rioja (Spain). Theoretical and Applied Genetics 97(1-2):51-59.

Cervera MT, Gussmão J, Steenackers M, Van Gysel A, Van Montagu M, Boerjan W (1996). Application of AFLP ${ }^{T M}$ - based molecular markers to breeding of Populusspp. Plant Growth Regulation 20(1):47-52.

Challice JS, Westwood MN (1973). Numerical taxonomic studies of the genus Pyrus using both chemical and botanical characters. Botanical Journal of the Linnean Society 67(2):121-148.

De Paoli G, Subirà E, Battistini A (2002). In vitro rooting of Pyrodwarf and Cydomalus, two rootstocks for pear, under photoautotrophic conditions. Acta Horticulturae 596:463-467.

Elkins R, Bell R, Einhorn T (2012). Needs assessment for future US pear rootstock research directions based on the current state of pear production and rootstock research. Journal of the American Pomological Society 66(3):153-163.

Food and Agricultural Organization (2016).http://www.fao.org/ .

Gao M, Yhou S, Guan J, Zhang Y (2015). Effects of 1-methylcyclopropene on superficial scald and related metabolism in 'Wujiuxiang' pears during cold storage. Journal of Applied Botany and Food Quality 88:102-108.

Hampl V, Pavlícek A, Flegr J (2001) Construction and bootstrap analysis of DNA fingerprinting-based phylogenetic trees with the freeware program FreeTree: application to trichomonad parasites. International Journal of Systematic andEvolutionary Microbiology 51:731-735.

Jackson J (2003). Biology of apples and pears. Cambridge. Cambridge University Press.

Jacob HB (1998). Pyrodwarf, a new clonal rootstock for high density pear orchards. ActaHorticulturae 475:169-178.

Kikuchi A (1946). Assessment of Chinese pear species and cultivars. Collected Records Horticulture Research, Faculty of Agriculture, Kyoto,Japan 3:1-11.

Koch V(1967).Hrušky [Pears]. Praha: Academia, 145pp.

Lin B, Shen D (1983). Studies on the germplasmic characteristics of Pyrus by use of isozymic patterns. Acta Agriculturae Universitis, Zhejiang, China 9:235-243.

Monte-Corvo L, Cabrita L, Oliveira C, Leitão J (2000). Assessment of genetic relationships among Pyrus species and cultivars using AFLP and RAPD markers. Genetic Resources and Crop Evolution 47(3):257265.

Monte-Corvo L, Goulão, L, Oliveira C (2002). Discrimination of Pear Cultivars with RAPD, AFLP ${ }^{\mathrm{TM}}$ and ISSR Acta Horticulturae 596:187-191.

Nečas T, Láćík J, Wolf J, Nečasová J (2016). Asijské odrůdy hrušní pro podmínky ČR [Asian pears varieties for region of Czech Republic] Zahradnictví 1:47.
Powell W, Morgante M, Andre C, Hanafey M, VogelJ, Tingey S, RafalskiA (1996). The comparison of RFLP, RAPD, AFLP and SSR (microsatellite) markers for germplasm analysis. Molecular Breeding 2(3):225-238.

Shen T(1980). Pears in China. HortScience 15(1):13-17.

Shen Y, Teng Y, Tanabe K(2006). RAPD analysis for genetic assessment of some cultivars of Pyrus pyrifolia derived from China and Japan. Acta HorticulturaeSinica33(3):621-624.

Shengua L, Chengquan F, Wenqin S, Feng Z (2002). AFLP molecular markers of 10 species of Pymus in China. Acta Horticulturae 587:233236.

Simonovik B, Ivancic A, Jakse J, Bohanec B (2007). Production and genetic evaluation of interspecific hybrids within the genus Sambucus. Plant Breeding 126(6):628-633.

Sisko M, Javornik B, Sifftar A, Ivancic A (2009). Genetic Relationships among Slovenian Pears Assessed by Molecular Markers. Journal of the American Society for Horticultural Science 134(1):97-108.

Tautz D, Trick M, Dover GA (1986). Cryptic simplicity in DNA is a major source of genetic variation. Nature 322(6080):652-656.

Teng Y (2004). Reconsideration on the Origin of Cultivated Pears Native to East Asia. Acta Horticilturae 634:175-182.

Teng Y, Tanabe K, Tamura F, Itai A (2001). Genetic relationships of pear cultivars in Xinjiang, China, as measured by RAPD markers. Journal of Horticultural Science and Biotechnology 76(6):771-779.

Teng Y, Tanabe K, Tamura F, Itai A (2002). Genetic relationships of Pyrus species and cultivars native to East Asia revealed by randomly amplified polymorphic DNA markers. Journal of the American Society for Horticultural Science 127(2):262-270.

Vavilov NI (1951). The origin, variation, immunity and breeding of cultivated plants. New York: The Ronald Press Company, 482 pp.

Vos P, Hogers R, Bleeker M, Reijans M, Van de Lee T, Hornes M, Friters A, Pot J, Paleman J, Kuiper M,Zabeau M (1995). AFLP: a new technique for DNA fingerprinting. Nucleic Acids Research 23(21):4407-4414.

Welsh J, McClelland M (1990). Fingerprinting genomes using PCR with arbitrary primers. Nucleic Acids Research 18(24):7213-7218.

Williams JG, Kubelik AR, Livak KJ, Rafalski JA, Tingey SV (1990). DNA polymorphisms amplified by arbitrary primers are useful as genetic markers. Nucleic Acids Research 18(22):6531-6535.

Wu J, Wang Z, Shi Z, Zhang S, Minq R, Zhu S, Zhang S (2013). The genome of the pear (Pyrus bretschneideri Rehd.). Genome Research 23(2):396-408.

Yu T (1979). Taxonomy of the fruit tree in China. Beijing: Agriculture Press (in Chinese).

Zou L, Zhang X, Zhang Z, Sun B, Guo S (1986). Studies on the systematic relationship of some of the species in the genus Pyrus based on pollen grain morphology. Acta HorticulturaeSinica 13:219-224. 